\title{
Cytotoxic activity of glycoalkaloids extract from fruits of Solanum lycocarpum A. St.-Hil
}

\author{
Flávia Barbosa', Mariza Miranda², Walace Rizo ${ }^{1}$, Bianca Bertoni ${ }^{1}$, Jairo Bastos ${ }^{2}$, Mozart Marins $^{1}$, Ana Fachin ${ }^{1 *}$ \\ From 5th Congress of the Brazilian Biotechnology Society (SBBIOTEC) \\ Florianópolis, Brazil. 10-14 November 2013
}

\begin{abstract}
Background
Phytochemical analysis of the fruits of Solanum lycocarpum, popularly known as "fruit of the wolf", showed high concentrations of steroidal alkaloids, such as solasonine and solamargine which are substances with potential cytotoxic activity [1]. The cytotoxic activity displayed by these compounds may be due to presence of sugar moieties (rhamnose). Since there is interaction of glycoalkaloids with plasma membrane cholesterol leading to loss of membrane integrity, resulting in alterations in its permeability what induces cell death [2]. The aim of this study was to evaluate the cytotoxicity activity of the glycoalkaloids solamargine and solasonine purified from S. lycocarpum and commercial $\alpha$-solanine alkaloid from potato sprout toward cell lines MCF-7 (human breast adenocarcinoma cell line), B16 (murine skin) and 3T3 (normal mouse embryo fibroblasts) by MTT.
\end{abstract}

\section{Methods}

The cells lines were cultured at $37^{\circ} \mathrm{C}$ in a humidified atmosphere containing $5 \%$ of $\mathrm{CO} 2$ supplemented with $15 \%$ fetal bovine serum, using Dulbecco's modified Eagle's medium (Sigma). Penicillin $(100 \mathrm{U} / \mathrm{mL})$, streptomycin $(100 \mathrm{ug} / \mathrm{mL})$ and ciprofloxacin $(100 \mathrm{ug} / \mathrm{mL})$ were added to the medium to prevent bacterial growth. A stock solution $(10 \mathrm{mg} / \mathrm{mL})$ of glicoalkaloid was prepared in 5\% DMSO. Solamargine, Solasonine purified from S. lycocarpum and alfa-Solanine (Sigma) was directly diluted in the medium to obtain concentrations ranging from 57.5 to $5.75 \mathrm{uM}$. The final concentration of DMSO was less than $0.5 \%$ and it had no negative effects on the cell lines. Cells were trypsinized $(0.15 \%$ trypsin and $0.02 \%$ EDTA), counted in a hemocytometer $(2.5 \mathrm{x}$ 105 cells/well), and incubated in a 96-well plate for $24 \mathrm{~h}$.

'Unidade de Biotecnologia, Universidade de Ribeirão Preto (UNAERP), Ribeirão Preto, Brazil

Full list of author information is available at the end of the article
After addition of the alkaloid or vehicle dissolved in fresh medium, the cells were cultured at $37{ }^{\circ} \mathrm{C}$ in a $5 \% \mathrm{CO} 2$ atmosphere for $48 \mathrm{~h}$, and cytotoxicity was analyzed by the MTT assay. For this purpose, $20 \mathrm{uL} \mathrm{MTT/well}$ ( $5 \mathrm{mg} / \mathrm{mL}$ in Hanks solution) were added to the 96-well plate, and the assay was incubated for $4 \mathrm{~h}$ under the same conditions. Hereafter, the plates were measured through $550 \mathrm{~nm}$ wavelength analysis, using an ELISA reader. Treatments were compared to negative control (medium with 0.5\% DMSO) and positive controls Doxorubicin $(0,258 \mathrm{uM})$ and actinomycin $\mathrm{D}(0,119 \mathrm{uM})$ [3] . Cytotoxicity was calculated by the formula: percent cytotoxicity $=(1$-[absorbance of experimental wells/absorbance of control wells]) $\times 100 \%$. IC50 values were also determined. Data were analyzed by the Sisvar software.

\section{Results and conclusion}

For the cell line MCF-7 the IC50 of Solamargine, solasonina and $\alpha$-solanine were $13.55,14.57 \mathrm{uM}$ and $51.23 \mathrm{uM}$, respectively. The $3 \mathrm{~T} 3$ cell line showed IC50 value of $20.11 \mathrm{uM}, 13.47$ and 49.79 of Solamargine, solasonina and $\alpha$-solanine, respectively. Tested compounds (solamargine, solasonina and $\alpha$-solanine) showed higher cytotoxicity to B16 with IC50 values of 34.075, 22.611 and $57.380 \mathrm{uM}$, respectively. Finally the tested glycoalkaloids showed pronunciated cytotoxity activity and may be further explored for the development of potential lead compounds active against cancer cells.

\section{Acknowledgements \\ This study was supported by grants from Fundação de Amparo à Pesquisa do Estado de São Paulo (2012/06889-7) and CAPES through fellowship granted to FRB. \\ Authors' details \\ 'Unidade de Biotecnologia, Universidade de Ribeirão Preto (UNAERP), Ribeirão Preto, Brazil. 'Laboratório de Farmacognosia, Faculdade de Ciências Farmacêuticas de Ribeirão Preto, University of São Paulo (USP-FCFRP), Brazil.}




\section{References}

1. Nakamura S, Hongo M, Sugimoto S, Matsuda H, Yoshikawa M: Steroidal saponins and pseudoalkaloid oligoglycoside from Brazilian natural medicine, "fruta do lobo" (fruit of Solanum lycocarpum). Phytochemistry 2008, 69:1565-1572.

2. Vieira PM, Da Costa PM, Silva CRS, Chen-Chen L: Assessment of the Genotoxic, Antigenotoxic, and cytotoxic activities of the ethanolic fruit extract of Solanum lycocarpum A. St. Hill. (Solanaceae) by Micronucleus Test in Mice. Journal of Medicinal Food 2010, 13(6):1409-1414, doi:10.1089/ jmf.2009.0295.

3. Rizo WF, Ferreira LE, Colnaghi V, Martins JS, Franchi LP, Takahashi CS, Beleboni RO, Marins M, Pereira PS, Fachin AL: Cytotoxicity and genotoxicity of coronaridine from Tabernaemontana catharinensis A.DC in a human laryngeal epithelial carcinoma cell line (Hep-2). Genet Mol Biol 2013, 36(1):105-110, doi: 10.1590/S1415-47572013005000010.

doi:10.1186/1753-6561-8-S4-P7

Cite this article as: Barbosa et al.: Cytotoxic activity of glycoalkaloids extract from fruits of Solanum lycocarpum A. St.-Hil. BMC Proceedings 2014 8(Suppl 4):P7.

\section{Submit your next manuscript to BioMed Central} and take full advantage of:

- Convenient online submission

- Thorough peer review

- No space constraints or color figure charges

- Immediate publication on acceptance

- Inclusion in PubMed, CAS, Scopus and Google Scholar

- Research which is freely available for redistribution

Submit your manuscript at www.biomedcentral.com/submit 